\title{
The Impact of Slavery in Toni Morrison's Beloved: From the Communal to the Individual
}

\author{
Mahameed Mohammed* \\ Department of English Language and Literature, Faculty of Arts and Sciences, Middle East University, Amman, Jordan \\ Corresponding Author: Mahameed Mohammed, E-mail: mmahameed67@yahoo.com
}

\section{ARTICLE INFO}

Article history

Received: April 02, 2018

Accepted: July 19, 2018

Published: November 01, 2018

Volume: 7 Issue: 6

Advance access: September 2018

Conflicts of interest: None

Funding: None

\begin{abstract}
Slavery is a condition of extreme physical, intellectual, emotional, and spiritual deprivation, a kind of hellish life. This paper aims at exploring how the culture of white racism sanctioned not only official systems of discrimination but a complex code of speech, behavior, and social practices designed to make white supremacy not only legitimate but natural and inevitable. In her masterpiece, Beloved (1987), Toni Morrison portrays the dehumanizing effects of slavery on the past and memory of her heroine. Morrison has dedicated her literary career to ensuring that black experience under, and as a result of, slavery would not be left to interpretations solely at the dictates of whites. This study shows how Toni Morrison has succeeded in revealing the physical and psychological damage inflicted on African American people by the brutal inhumanity that constituted American slavery. The paper, in this context, investigates how the memory and the past of the heroine act as destroyers of her motherly existence.
\end{abstract}

Key words: Morrison, Slavery, Consciousness, Trauma, Dehumanization

\section{INTRODUCTION}

Slave narratives are important not only for the fact they enrich and diversify African American literature, but also because they reveal the complexities of the dialogue between Whites and Blacks. The Africa-American experience started when colonists bought twenty black people from "a Dutch Man of Warre" Trotter, 2001, p. 58), in Virginia, 1619. White prejudice started to emerge as the introduction of racial laws became viable. In 1664, officials of Maryland ordered: "that all Negroes or other Slaves... shall serve Durante Vita and all children born of any Negro or other slaves shall be slaves as their fathers were for the term of their lives". (Holt \& Brown, 2000 , p. 89). The state of Virginia, given the fact that they had brought people who had every reason to be defiant, endorsed in the late 1600 s and early 1700 s laws castigating the Blacks to be punished more severely than others for "being a brutish sort of people and reckoned as goods and chattels" (Morgan, 2000, p. 106). With these inhuman laws Virginians did not spare any chance to oppress the black slaves by denying them even basic rights and inflicting upon them severe punishments.

The idea that Blacks were immoral, dissipated, and compliant occupied the minds of the first English men who went to Africa to buy slaves. They misunderstood black practice, according to tribal traditions and tropical climate, as lustfulness. This idea was confirmed as the black women, working on American farms, often worked bent over. Thus, the body of a slave woman did not summon any respect, and was therefore the target of the master who sexually abused his black slave girls and women. As this mentality became commonly and applicable to many areas of the new continent, numbers of survivors were less, the thousands of slaves were sold, transported, and even stripped of their African names. This dehumanizing process was maintained by white colonists in rural and urban areas to ensure the prosperity and satisfaction of the white colonists.

When importing slaves became unlawful in1808, resources had already been in danger of drying up. However, the trafficking of slaves continued, and slaveholders and influential people were benefitting from its continuation. But with these restraints on importing slaves, coupled with the growing demand for the black labor, there came the need for female slaves, who were valued for their reproductive potential. Thus, the slave owner wished "to turn every young black woman into a brood mare”. (White, 1999, p. 72). This tendency for reproduction turned slaves into commodities valued only as merchandise. In the process, much pressure was exerted on mothers and children in slavery, some preferred to stay with an implied consent for sexual submission. Accordingly, in the slave community, women became the focus of familial relationships, and in such a community there came the "supremacy of the mother-child bond over all other relationships". (White, 1999, p. 275). Female slaves were compelled, psychologically and physically, to experience the severe mental and physical pain of slavery. White masters used all psychological and physical means to force slaves into obedience, and in the case of black females, this had the added dimension of sexual submission. Thus, as one 
may see, over the years of slavery in American, Black people were reckoned as animals and commodities, exploited, abused, and denied basic rights. Till Abolitionists intensified their campaign in 1865 to rid the country of slavery, when freed Blacks saw themselves as American.

While African Americans have been part of American life, participating in, and contributing to, American culture, the American history of slavery had been consciously consigned to oblivion. Toni Morrison, one of the most significant voices of her race and age, observes that "We were seldom invited to participate in the discourse, even when we were its topic." (Morrison, Beloved, 1987, p. 111). As people who did not write their history, African Americans have always felt the need for a sense of knowing their past in order to find a viable association with the present and future. Morrison understands her mission to be recovering and reconstructing the experiences of these people "Because if we do not know. .. what our past is ... if we Third-World women in American do not know it, then, it is not known by anybody at all. And somebody has to tell somebody something." (Morrison, Beloved, 1987, p. 59).

\section{DISCUSSION}

A growing interest in African American studies and black writing, in general, emanated from the Civil Rights and Black Power monuments of the 1960s and the 1970s. Toni Morrison's major pre-occupation in literature has always been to what Morrison's narratives private lives that form the experience of a community. What Morrison's narratives, in particular, try to convey is the idea that there is more than one type of knowledge, and that it is necessary to accept different modes is not based on the factual but on the aural and the visual. Thus, she has embarked upon showing how an African American author tackles the institution of slavery.

Slavery is horrible for men, but it is more horrible for women, it inflicted harm upon families, where men and women had suffered. The concept of family, in the traditional sense, was not even perceived before 1865 among black communities. "Slavery not only inhibited family formation but made stable, secure family life difficult if not impossible" (Williams, 2017, p. 1). In the consciousness of many African-American women, under slavery and after, there implanted an image of a horrible part, reminding them of degrading submission. Sexual abuse was one of the cruelest hardships endured by enslaved African-Americans, practices by their slaveholders. Enslaved women were forced to submit to their masters' sexual advances, perhaps bearing children from whom they might be separated forever as a result. In fact, these experiences obliterate any opportunity for a black woman to have a clear memory and a viable past. Toni Morrison, in her Beloved, tackles this point in particular. It is a novel of "Futile forgetting and persistent remembrance. Operating independently of the conscious will, memory is shown to be an active, constitutive force that has the power to construct and circumscribe identity, both individual and collective..." (Lawrence, 2007, p. 45).

In Encyclopedia and Dictionary of Medicine, Nursing, and Allied Health, memory is defined as "the mental faculty that enables one to retain and recall previously experienced sensations, impressions, information, and ideas". (Kean, 2003 , p. 271). It is man's ability to recall past experiences and give him/her capability to adapt from previous experiences as well as to build relations. In fact, Toni Morrison in Beloved portrays the impact of slavery experiences on the memory of society and that of the individual, who is denied in the process any sense of workable and meaningful past. The individual, in such a battle, is caught at the center of a war imposed by a past that refuses to die. To build relationships in such a bleak, tantalizing, and thwarting existence would seem futile. Toni Morrison succeeds in embodying these concepts in the character of Sethe. The narrative voice of Beloved is mostly here as she relives and Imemories' the distress of her slavery life. Eighteen years have passed since Sethe escaped from Slavery. After her escape to Cincinnati with her four children, Sethe was eventually chased by her old master. Rather than having children return slavery, she attempted to kill all of them, succeeding only in killing her baby girl. She lived with her remaining children and her mother-in-law. The ghost of the dead baby began to haunt their house, causing to perpetrate Sethe's suffering. She was still haunted by the pain of the past. A girl named Beloved came to visit the family, and it gradually became clear that she was the ghost of the dead baby. Beloved lives with Sethe, proving to be powerful and malicious. On discovering Beloved's identity, Sethe believed that she had been given a second chance. Sethe tried to make amends for the past, but the girl's needs were devouring. The ghost did not forgive Sethe for the actions. A group of women came to force the ghost to leave, but Sethe is almost destroyed.

As a slave narrative, Beloved is written with the evident purpose of revealing that the black is a human capable of reasoning and judgment. Slave narratives usually speak for the majority who cannot narrate their own stories, due to the fact blacks have not been given the opportunity to receive education. As one former slave woman wrote: "We were no more than dogs. If they caught us with a piece of paper in our pockets, they'd whip us. They were afraid we'd learn to read and write, but I never got the chance. (Ward and Burns, 1991, p. 9). Sethe, in Morrison's Beloved, is not only deprived of the opportunity to receive education but also the right to be a human being, playing her natural role of mothering. Sethe's complex life under slavery makes her believe that children are better off dead; better forced to come to the conviction that, it is better to die in the cradle than to live a degrading life of submission. As one may notice, in Toni Morrison's Beloved, the slavery experience in the life of almost all her characters acts as a devouring past: Baby Suggs, Sethe's mother-in-law, is a practical example of the brutality of the past, the slave system, suffering from sexual abuse and lack of normal maternal affection. Commenting on Baby Suggs' tragic stance in slavery life, Stamp Paid, one of the minor characters of Beloved, remarks:

'Sixty years of losing children to the people who chewed up her life... five years of freedom given to her by her last child, who bought her future with his...to lose him too; to acquire a daughter.see.. that daughter slay the children (or 
try to); to belong to a community of... free Negroes. and then have that community step back and hold itself at a distancewell, it could wear out even a baby Suggs, holy'. (Morrison, Beloved, 1997, p. 177).

Sethe is the embodiment of a traumatic and devouring past, a character in whose personality, the reader perceives the painful loss of a true maternal love. The weight of the past has diminished the possibility of a meaningful present and a promising future, Paul D tells Sethe that together they have "move yesterday than anybody. We need some kind of tomorrow" (Morrison, Beloved, 1997, p. 273). Seethe also understands that "her brain wan not interested in the future. Loaded with the past and hungry for more, it left her no room to imagine, let alone plan for, the next day." (Morrison, Beloved, 1997, p. 70). An inescapable force in Sethe's life, the past has exerted a tremendous impact upon her present to the extent that has cannot envision any sense of the future. Sethe's traumatic memory thus controls her whole existence. She tells her daughter, Denever, that "nothing ever dies, and that the pictures and images of things remain" (Morrison, Beloved, 1997, p. 36). A meaningful present, in the case of Sethe, is to be a woman living in a community and maintaining healthy relationships with others, and to be a good mother in particular. The haunting of the communal past and the tyranny of the memories turn Sethe into a crippled character, socially and spiritually. It becomes evident that "In portraying the capacity of the past to haunt individual and community life in the present, Beloved brings into daylight" the ghosts that one harbored by memory and that hold their 'hosts' in thrall, tyrannically dictating thought, emotion, and action. (Lawrence, 2007, p. 45).

Toni Morrison in Beloved, reveals how these ghosts, which are 'harbored by memory', devour the memory of the community and the individual. This makes Sethe oscillate between remembering and forgetting, preferring to forget to 'disremember the past. Beloved, Sethe's baby ghosts who returns to live with her mother and her sister, Denever, functions as a scapegoat for the evils of the past, and as a vehicle to free the community from these evils. However, Beloved's return and mere existence deepens Sethe's sense of guilt, her fragmented memory, and her loss of maternity. Although Beloved's presence in the novel is a negative one, she helps in releasing Sethe's guilt; this point helps Sethe who needs punishment in order to gain redemption. In most parts of the novel, Sethe faces a multifaceted battle whose psychological and emotional impacts have left her benefit, with enduring heartbreak. Sethe, unconsciously, accepts the punishment inflicted by Beloved; Morrison finds that this becomes aptly necessary in a life of suffering and agony.

Morrison, in this way, tries to help Sethe repulse the past through this process of needing punishment, in order to gain redemption and have a sustainable life. Sethe has to confront the evils and darkness of the communal and individual past in order to free herself from their tantalizing impacts. Thus, Morrison uses to extends the power of revelation to her characters who uncover the hidden degradation they suffer; when they are ready to put their memories into words, Morrison states that "the collective sharing of that information heals the individual - and the collective". (Morrison, Beloved, 1997, p. 248). Morrison has provided the reader with a subtext with the unprofessed intention to unravel the unspeakable things Sethe is trying, and with the deliberate objective to move the reader engage in the fictional and realistic world of the narrative. Therefore, she moves between the past and the present, memory and fact, memory and memory. etc... Morrison's mode of writing is characterized by being crafty and creatively skilful:

"She was not thinking of the atrocity the men committed on her, or the reason for her scared back, but by this negation, the reader has been made aware of the horrible sexual act that she has been physically abused. Then... Her boy lapping in the puddle near her feet, and suddenly there was Sweet Home rolling. out before her eyes... it made her wonder if hell was a pretty place too... the most innocent occurrence or image has connotations that bring back the horror of what happened at the picturesque Sweet Home.". (Morrison, Beloved, 1997, pp. 6-107).

In order to shun herself from these traumatic memories and thoughts, Sethe has not only to forget them, but also to cope with her realistic life and individual traumas, Sethe's journey from slavery to freedom starts with her awareness of the necessity to rid her children in the first place from slavery life. As Sethe is reunited with her other three children in freedom, she radiates with her new-found freedom:

I was big; Paul D, and deep and wide and when I restricted out my arms all my life could get in between. I was that wide. Look like I loved em more after I got here. Or maybe I could not love em proper in Kentucky because they wasn't mine to love. But when I got here, when I jumped down off that wagon - there wasn't nobody in world I couldn't love if I wanted to. (Morrison, Beloved, 1997, p. 162).

Though the existence of Beloved in Sethe's life, after her escape from Sweet Home, has brought the latter complications, it has rekindled feelings of love in the heat of the mother; but Sethe wants Beloved to understand the reasons for her past actions. It is thus through love and maternal affection Sethe is able to unburden herself from all her bad memories. Sethe's commitment, unyielding affection, and uncompromising relationship with her children have rendered her admirable in the eyes of readers towards the end of the novel.

\section{CONCLUSION}

In this paper, attention is converged upon discussion of the influence of slavery on the collective past of the community and the memory of the individual through the experience of motherhood. Toni Morrison has skillfully delved into how the traumatic collective past of the Blacks and the heroine's own memory leads to distorted experience of motherhood. However, the heroine succeeds in overcoming these haunting experiences through growing awareness and forbearance. Toni Morrison, in Beloved, points out the necessity of new beginnings and faith that the Blacks should maintain in order to live as free people. Thus, Morrison has succeeded in showing African American how to exercise the ghosts of slavery and the horrible 
communal past. Through Sethe's sense of hope towards the end of the novel, Morrison has given African American hope for the future. In doing so, Morrison has brought the individuals and the community together; she has revealed that Blacks and Whites have successfully achieved a sense of cooperation.

\section{REFERENCES}

Bloom, H. (2007). Toni Morrison's Beloved. New Delhi: Viva Books.

Holt, Thomas C., Thomas, B., and Elisa, B. (2000). Major Problems in African History: Vol. 1, From Slavery to Freedom, 1619-1877. Boston: Houghton Mifflin Company, pp. 89-90.

Lawrence, D. (2007). "Fleshly Ghosts and Ghostly Flesh”. The Word and the Body in Beloved," Toni Morrison's Beloved; ed. By Harlod Bloom. New Delhi: Viva Books.

Miller, K. (2017). Encyclopedia and Dictionary of Medicine, Nursing and Allied Health, $7^{\text {th }}$ edition Ed., by Saunders Inc 2003. Accessed in $-\mathrm{a} h \mathrm{href}=\mathrm{http} / /$ medical Dictionary-the freedictionary.com., accessed in Feb. 2017.

Morgan, E.S. (2000). "The Paradox of Slavery and Freedom". Major Problems in African-American History;
Vol. 1: From Slavery to Freedom, 1619-1877. Boston: Houghton Mifflin Company. 106.

Morrison, T. (1987). "The Site of Memory." Inventing the Truth; The Art and Craft of Memoir. William Zeissman (ed). Boston: Houghton Mifflin Company.

Morrison, T. (1987). Beloved. London: Random House, UK Ltd. Taylor, G.D. (1994). In the Realm of Responsibility A conversation with Toni Morrison, Conversations with Toni Morrison. Jackson: University Press of Mississippi.

Trotter, J., \& Williams, J. (2001). The African American Experience. Boston: Houghton Mifflin Company.

Ward, G.C., \& Burn, R.K. (1991). The Civil War. London: the Bodley Head.

White, D. (2000). "Gender Roles and Gender Identity in Slave Communities". Major Problems in African American History: Vol. 1, From Slavery to Freedom, 16191877. Boston: Houghton Mifflin Company.

White, D. (1999). Aren't I a Woman?, Female Slaves in the Plantation South. New York: W. W. Norton Company.

Williams, H.A. (2017). "How Slavery Affected African American Families.” Freedom's Story. Teacher Serve. National Humanities Center. Accessed Http://national humanitiescentre.org/tserve/freedom/1609-1865/families.htm. accessed in Feb. 2017. 